\author{
JANUSZ SŁUGOCKI \\ ORCID: 0000-0002-4018-409X \\ Uniwersytet Szczeciński \\ janusz.slugocki@usz.edu.pl
}

\title{
Uwagi o międzywojennym prawie opieki nad zabytkami a model współczesny
}

\begin{abstract}
Abstrakt: Współczesny system ochrony zabytków w Polsce wywodzi się z rozwiązań przyjętych w okresie międzywojennym. Szczególne znaczenie przypisuje się uchwaleniu przez Radę Regencyjną dekretu o opiece nad zabytkami sztuki i kultury w 1918 roku. Dokument był pierwszym aktem prawnym dotyczącym opieki nad zabytkami i ochrony zabytków. Międzywojenny system prawny ochrony zabytków został ostatecznie ukształtowany przepisami rozporządzenia Prezydenta Rzeczypospolitej o opiece nad zabytkami wydanego 6 marca 1928 roku. Obecnie w pełni należy potwierdzić pogląd o szczególnej, wręcz fundamentalnej, roli regulacji prawnych z okresu międzywojennego do budowy systemu prawa ochrony zabytków i opieki nad zabytkami. Do dziś aktualne są przede wszystkim problemy terminologiczne. W polskim systemie prawnym w odniesieniu do roli państwa wobec dziedzictwa kulturowego przyjęto trzy terminy o charakterze zbliżonym znaczeniowo: „strzeżenie”, „ochrona” i „opieka”. Należy zaznaczyć, że ostatnia ustawa (z dnia 23 marca 2003 roku) nadała pojęciu „opieka nad zabytkami” inne znaczenie niż przyjmowane w okresie międzywojennym. Dzisiaj, w XXI wieku, opieka nad zabytkiem jest sprawowana przez jego właściciela lub posiadacza i polega w szczególności na zapewnieniu odpowiednich warunków zachowania zabytku. Ponadto należy zauważyć, że podstawowe problemy, z którymi próbowano się uporać na początku ubiegłego stulecia, nadal nie są rozwiązane, co znajduje swoje odzwierciedlenie zarówno w literaturze przedmiotu, jak i w orzecznictwie.
\end{abstract}

Słowa kluczowe: ochrona zabytków, opieka nad zabytkami, okres międzywojenny.

\section{Uwagi wprowadzające}

Obecny system ochrony zabytków w Polsce wywodzi się z rozwiązań przyjętych w okresie międzywojennym. Szczególne znaczenie przypisuje się uchwaleniu 
przez Radę Regencyjną dekretu o opiece nad zabytkami sztuki i kultury ${ }^{1}$ w 1918 roku, który był pierwszym aktem prawnym dotyczącym opieki nad zabytkami. J. Pruszyński trafnie przedstawił jego rolę, wskazując, że był ,aktem mającym podstawowe znaczenie dla kształtowania ochrony zasobu kulturalnego i fundamentem całej budowli organizacji ochrony"2.

Funkcjonujący w okresie międzywojennym system ochrony zabytków w Polsce został ostatecznie ukształtowany przepisami wydanego 6 marca 1928 roku rozporządzenia Prezydenta Rzeczypospolitej o opiece nad zabytkami ${ }^{3}$. W myśl tego rozporządzenia opiekę nad zabytkami sprawowały „władze konserwatorskie”, czyli właściwe organy administracji publicznej. Kolejną istotną zmianę w obowiązującym systemie ochrony zabytków w Polsce wprowadziła ustawa o ochronie dóbr kultury ${ }^{4}$, na mocy której określono pojęcie ochrony zabytków jako wyłącznej kompetencji państwa. Od 2003 roku problematykę ochrony zabytków w Polsce reguluje ustawa rozgraniczająca pojęcia ochrony zabytków jako kompetencji organów administracji rządowej oraz opieki nad zabytkami, traktowanej jako zadanie właścicieli lub innych dysponentów poszczególnych zabytków ${ }^{5}$.

\section{Problemy terminologiczne - przemiany znaczeń podstawowych pojęć}

Do dziś aktualne są problemy terminologiczne. W polskim systemie prawnym w odniesieniu do roli państwa wobec dziedzictwa kulturowego przyjęto trzy zbliżone znaczeniowo terminy: „strzeżenie”, „ochrona” i „opieka”. W literaturze podkreśla się, że interpretację pojęć prawnych utrudnia bliskoznaczność czasowników: „strzec”, „chronić” i ,otaczać opieką"6.

Należy od razu zaznaczyć, że ostatnia ustawa nadała pojęciu „opieka nad zabytkami” inne znaczenie niż przyjmowane w okresie międzywojennym. Opieka nad zabytkiem sprawowana przez jego właściciela lub posiadacza polega w szczególności na zapewnieniu warunków: naukowego badania i dokumentowania za-

1 Dekret Rady Regencyjnej z dnia 31 października 1918 roku o opiece nad zabytkami sztuki i kultury, Dziennik Praw Państwa Polskiego z 1918 r. Nr 16, poz. 36.

2 J. Pruszyński, Dziedzictwo kultury Polski. Jego straty i ochrona prawna, t. 1, Kraków 2001, s. 342 .

3 Rozporządzenie Prezydenta Rzeczypospolitej z dnia 6 marca 1928 roku o opiece nad zabytkami, Dz.U. z 1928 r. Nr 29, poz. 265.

${ }^{4}$ Ustawa z dnia 15 lutego 1962 roku o ochronie dóbr kultury, tekst jedn. Dz.U. z 1999 r. Nr 98, poz. $1150 \mathrm{ze}$ zm.

${ }^{5}$ Ustawa z dnia 23 lipca 2003 roku o ochronie zabytków i opiece nad zabytkami, tekst jedn. Dz.U. z 2020 r. poz. 282.

6 J. Pruszyński, op. cit., s. 514. 
bytku; prowadzenia prac konserwatorskich, restauratorskich i robót budowlanych przy zabytku; zabezpieczenia i utrzymania zabytku oraz jego otoczenia w jak najlepszym stanie; korzystania z zabytku w sposób zapewniający trwałe zachowanie jego wartości, a także popularyzowania i upowszechniania wiedzy o zabytku oraz jego znaczeniu dla historii i kultury. W orzecznictwie wskazuje się, że w świetle ustawy z dnia 23 lipca 2003 roku o ochronie zabytków i opiece nad zabytkami, opieka nad zabytkiem ma charakter zindywidualizowany, gdyż odpowiedzialny za jej realizację jest aktualny dysponent zabytku, zwłaszcza jego aktualny właściciel ${ }^{7}$.

Zgodnie z art. 1 dekretu Rady Regencyjnej z 1918 roku wszelkie zabytki kultury i sztuki znajdujące się w granicach państwa polskiego, wpisane do inwentarza zabytków sztuki i kultury, podlegały opiece prawa. Należące do państwa polskiego lub jego obywateli, lub instytucji polskich zabytki sztuki i kultury znajdujące się za granicą mogły być przedmiotem szczególnych środków ochrony ze strony polskiej władzy państwowej oraz umów międzynarodowych, stosownie do osobnych $\mathrm{w}$ tej mierze postanowień. W dekrecie objęto opieką prawa, czyli ochroną, zabytki sztuki i kultury wpisane do inwentarza zabytków sztuki i kultury, jak również zabytki do niego niewpisane. W myśl art. 11 dekretu wszelkie nieruchome i ruchome dzieła świadczące o sztuce i kulturze z epok ubiegłych, istniejące nie mniej niż pięćdziesiąt lat, korzystały z opieki prawa, zanim zostały wpisane do inwentarza zabytków sztuki i kultury. Korzystały z niej także wszelkie wykopaliska i znaleziska, które z natury rzeczy nie mogły być uprzednio inwentaryzowane. $Z$ kolei dzieła ruchome istniejące mniej niż pięćdziesiąt lat mogły zostać uznane za zabytki na mocy specjalnej decyzji wydawanych przez ministra wyznań religijnych i oświecenia publicznego. Zabytki nieruchome podlegały opiece prawnej bez względu na typ własności; spośród ruchomych natomiast opiece podlegały tylko te będące własnością publiczną ${ }^{8}$. Jednocześnie w myśl art. 15 dekretu każdy właściciel zabytku nieruchomego był zobowiązany do utrzymywania go w stopniu niezbędnym do jego istnienia. Rząd, jeżeli występowały ku temu wyjątkowe powody, mógł pomagać właścicielowi w utrzymaniu zabytku.

$\mathrm{W}$ art. 5 rozporządzenia prezydenta z 1928 roku przewidziano z kolei, że opiekę nad zabytkami miały sprawować „władze konserwatorskie”. Jednocześnie w art. 16 tego rozporządzenia wskazano, że właściciel (posiadacz) zabytku winien utrzymywać go w należytym stanie. Zabytkiem w rozumieniu rozporządzenia był, zgodnie z art. 1, każdy przedmiot tak nieruchomy, jak i ruchomy, charakterystyczny dla pewnej epoki, mający wartość artystyczną, kulturalną, historyczną, archeologiczną lub paleontologiczną stwierdzoną orzeczeniem władzy państwowej i zasługujący wskutek tego na zachowanie. Jednakże od strony praktycznej rozpo-

7 Wyrok WSA w Warszawie z dnia 24 lutego 2015 roku, sygn. VII SA/Wa 2150/14, CBOSA (Centralna Baza Orzeczeń Sądów Administracyjnych).

${ }^{8}$ K. Zimna-Kawecka, Ochrona zabytków i organizacja urzędów konserwatorskich $w$ Polsce okresu międzywojennego (na przykładzie woj. pomorskiego) a unormowania Ustawy z dn. 23 VII 2003 r. o ochronie zabytków i opiece nad zabytkami, „Wiadomości Konserwatorskie” 2010, nr 27. 
rządzenie wprowadzało zupełnie nowe podejście, gdyż zgodnie z art. 3 przedmioty otrzymywały charakter zabytków w znaczeniu tego rozporządzenia dopiero na skutek orzeczenia organu konserwatorskiego pierwszej instancji, stwierdzającego wartość zabytkową przedmiotu, a nadto przy zabytkach nieruchomych określającego granice zabytku i otoczenia podlegającego przepisom tego rozporządzenia. Przedmioty te podlegały ochronie prawa już od chwili doręczenia orzeczenia. Orzeczenie organu służby konserwatorskiej, stwierdzające wartość zabytkową przedmiotu będącego częścią składową nieruchomości wpisanej do ksiąg gruntowych (wieczystych), doręczane było właściwemu oddziałowi Prokuratorii Generalnej w celu wpisania do tych ksiąg w sposób odpowiadający przepisom o ich prowadzeniu. Organ miał prawo umieszczenia na zabytku nieruchomym odpowiedniego znaku lub napisu.

W kolejnej ustawie — z dnia 15 lutego 1962 roku o ochronie dóbr kultury pojęcie zabytku oznaczało dobra kultury wpisane do rejestru zabytków lub w muzeach do inwentarza, wchodzące w skład bibliotek oraz inne, jeżeli ich charakter zabytkowy był oczywisty. Obecna ustawa o ochronie zabytków i opiece nad zabytkami z 2003 roku definiuje zabytki jako nieruchomości lub rzeczy ruchome, ich części lub zespoły będące dziełem człowieka lub związane z jego działalnością i stanowiące świadectwo minionej epoki bądź zdarzenia, których zachowanie leży w interesie społecznym ze względu na posiadaną wartość historyczną, artystyczną lub naukową. B.J. Rouba podkreśla różnice zakresu obu regulacji: „w stosunku do wcześniej obowiązującej ustawy o ochronie dóbr kultury z 1962 roku pole ochrony zostało tu zawężone wyłącznie do zabytków. Ustawowa ochrona nie obejmuje więc dóbr kultury współczesnej, choćby nawet były najcenniejsze"9. W ustawie o ochronie zabytków i opiece nad zabytkami, w zestawieniu z poprzednią ustawą, kluczowe przestaje być pojęcie dobra kultury, a znaczenia nabiera, podobnie jak w okresie międzywojennym, pojęcie zabytku.

Z ustawy o ochronie zabytków i opiece nad zabytkami z 2003 roku nie wyeliminowano jednak pojęcia dobra kultury, choć występuje ono w niej pomocniczo, w swoim najszerszym znaczeniu, w celu wskazania, że pojęcie to obejmuje również zabytki. Mieszczą się w nim jednak także inne kategorie przedmiotów i artystycznych środków wyrazu, których nie można zaliczyć do zabytków. Odniesienie to nawiązuje do pojęcia dobra kultury stosowanego w Konstytucji RP i umowach międzynarodowych. A. Tomaszewski podkreśla, że pojęcie dóbr kultury jest apolityczne i aideologiczne, gdyż obejmuje wszystkie dobra stworzone ludzkim talentem, mające „obiektywną” wartość historyczną i artystyczną. Tworzy je kulturalny i artystyczny dorobek ludzkości, podlegający jedynie warto-

9 B.J. Rouba, Teoria w praktyce polskiej ochrony, konserwacji i restauracji dziedzictwa kultury, [w:] Współczesne problemy teorii konserwatorskiej w Polsce, red. B. Szmygin, Warszawa-Lublin 2008, s. 103. 
ściowaniu estetycznemu według przyjętych kryteriów ${ }^{10}$. Znajduje to również odzwierciedlenie w odmiennej terminologii, gdyż podstawowego znaczenia nabiera w tym kontekście pojęcie dziedzictwa kulturowego. I. Szmelter pisze, że obecnie pojęcie „dziedzictwo kulturowe” jest

definiowane jako przedmiot zainteresowania teorii konserwatorskich, a nie np. wywodzący się z polskiej tradycji językowej „zabytek” — jako świadectwo dawnego bytu. Jest to termin o bardziej szerokim znaczeniu, aktualności i adekwatności w stosunku do obecnie rozszerzonego spektrum ochrony. Odnosi się do ogólnoświatowego, uniwersalnego znaczenia dziedzictwa kultury obejmującego także polską specyfikę ${ }^{11}$.

W naukach społecznych podjęto wiele prób zdefiniowania terminu ,zabytek", ale nie wypracowano jego jednoznacznej definicji stosowanej w nauce ${ }^{12}$. G. Bukal wyjaśnia, że „kryterium czasowe pozwalało na łatwą, automatyczną identyfikację obiektu zabytkowego, bo to, co jest stare, jest zabytkiem", ale dodaje także, że samo pojęcie wieku może być „relatywne i zmienne, i o jego słuszności lub nie można by długo dyskutować"13. B. Szmygin z kolei podkreśla, że „,idealistycznym celem ochrony zabytków jest ich utrzymanie w oryginalnej postaci i przekazanie przyszłym pokoleniom”"14. K. Płażyńska stwierdza, że „ocena, czy zachowanie konkretnego zabytku leży w interesie społecznym, wiąże się z arbitralnością opinii w tym zakresie, wynikającą z tego, że objęcie ochroną prawną zabytku jest konsekwencją decyzji administracyjnej, która nie jest uzależniona od głosu społecznego"15. Jak zauważa J. Pruszyński, „w sensie prawnym zabytek to jedynie przedmiot wpisany do urzędowego repertorium noszącego nazwę rejestru zabytków, prowadzonego przez właściwy organ administracji publicznej"16.

\section{Zasady prowadzenia rejestru zabytków}

W art. 5 dekretu Rady Regencyjnej z 1918 roku przewidziano prowadzenie przez Ministerstwo Wyznań Religijnych i Oświecenia Publicznego inwentarza za-

10 A. Tomaszewski, Ekumenizm kulturowy w jednoczacej się Europie, [w:] O zabytkach. Opieka, ochrona, konserwacja, red. T. Rudkowski, Warszawa 2005, s. 9.

11 I. Szmelter, Paradygmat teorii i praktyki konserwatorskiej w odniesieniu do sztuki nowoczesnej, [w:] Wspótczesne problemy teorii konserwatorskiej..., s. 133.

12 M. Drela, Definicja zabytku nieruchomego w prawie polskim i francuskim, „Ochrona Zabytków" 2008, nr 1, s. 111.

13 G. Bukal, Produkcja zabytków jako problem konserwatorski (przyklad Gdańska), [w:] Wspótczesne problemy teorii konserwatorskiej..., s. 22.

14 B. Szmygin, Teksty doktrynalne w ochronie dziedzictwa - analiza formalna i propozycje, [w:] Wspótczesne problemy teorii konserwatorskiej..., s. 145.

${ }^{15}$ K. Płażyńska, Świadectwo minionej epoki czy dobro kultury wspótczesnej? Problemy ochrony prawnej architektury nowoczesnej, [w:] Prawo ochrony zabytków, red. K. Zeidler, Gdańsk 2014, s. 108-109.

16 J. Pruszyński, op. cit., s. 76. 
bytków sztuki i kultury znajdujących się w granicach państwa polskiego. Kwestie te regulowane były przez rozporządzenie Ministra Sztuki i Kultury z 1919 roku w przedmiocie wpisywania zabytków sztuki i kultury do inwentarza ${ }^{17}$.

Zgodnie z art. 4 rozporządzenia prezydenta z 1928 roku władze konserwatorskie pierwszej instancji powinny prowadzić rejestr zabytków. Sposób prowadzenia rejestru określało rozporządzenie Ministra Wyznań Religijnych i Oświecenia Publicznego z dnia 17 lipca 1928 roku o prowadzeniu rejestru zabytków ${ }^{18}$. Rejestr zabytków opierał się na założeniu, że administracja państwowa podejmuje się opieki nad pewnym zbiorem zabytków i wprowadza system nakazów i zakazów regulujących wszelkie działania, które mogą być w tym zabytku prowadzone. Kolejne akty prawne regulujące zasady ochrony zabytków w Polsce wprowadzały jedynie modyfikacje odnośnie do zasad jego prowadzenia; o wpisie do rejestru, a tym samym uznaniu obiektu za zabytek, decydowali wojewódzcy konserwatorzy zabytków przez wydanie stosownej decyzji administracyjnej ${ }^{19}$.

Wpisanie zabytku nieruchomego do rejestru ujawnia się w księdze wieczystej danej nieruchomości na wniosek wojewódzkiego konserwatora zabytków na podstawie decyzji o wpisie tego zabytku do rejestru. Zabytek ruchomy wpisuje się do rejestru na podstawie decyzji wydanej przez wojewódzkiego konserwatora zabytków na wniosek właściciela tego zabytku. Wojewódzki konserwator zabytków może wydać z urzędu decyzję o wpisie zabytku ruchomego do rejestru w przypadku uzasadnionej obawy zniszczenia, uszkodzenia lub nielegalnego wywiezienia zabytku za granicę albo wywiezienia za granicę zabytku o wyjątkowej wartości historycznej, artystycznej lub naukowej. Jednakże do rejestru nie wpisuje się zabytku wpisanego do inwentarza muzeum lub wchodzącego w skład narodowego zasobu bibliotecznego.

Zgodnie z art. 9 ust. 1 ustawy o ochronie zabytków i opiece nad zabytkami z 2003 roku do rejestru wpisuje się zabytek nieruchomy na podstawie decyzji wydanej przez wojewódzkiego konserwatora zabytków z urzędu bądź na wniosek właściciela zabytku nieruchomego lub użytkownika wieczystego gruntu, na którym znajduje się zabytek nieruchomy. W myśl art. 10-11 ustawy z 2003 roku jedynym organem ochrony zabytków mającym kompetencje do wpisywania zabytków do rejestru jest właściwy terytorialnie wojewódzki konserwator zabytków.

$\mathrm{W}$ ostatnich latach kilkakrotnie zmieniano rozporządzenie dotyczące prowadzenia rejestru — aktualne rozporządzenie pochodzi z 2011 roku, poprzednie

17 Rozporządzenie Ministra Sztuki i Kultury z dnia 5 kwietnia 1919 roku w przedmiocie wpisywania zabytków sztuki i kultury do inwentarza, M.P. z 1919 r. Nr 81.

18 Rozporządzenie Ministra Wyznań Religijnych i Oświecenia Publicznego z dnia 17 lipca 1928 roku o prowadzeniu rejestru zabytków, Dz.U. z 1928 r. Nr 76, poz. 675.

19 Krajowy program ochrony zabytków i opieki nad zabytkami - Komunikat Ministra Kultury i Dziedzictwa Narodowego z dnia 20 sierpnia 2014 roku o podjęciu przez Radę Ministrów uchwały w sprawie ustanowienia programu wieloletniego „Krajowy program ochrony zabytków i opieki nad zabytkami”, M.P. z 2014 r. poz. 733, s. 21. 
— z 2004 roku $^{20}$, a jeszcze wcześniejsze - z 2000 roku $^{21}$. Jeszcze inne przepisy wprowadzało dawniejsze rozporządzenie Rady Ministrów z dnia 23 kwietnia 1963 roku $^{22}$, które obowiązywało w latach 1963-2000, czyli w okresie, gdy dokonano najliczniejszych wpisów.

Obecnie sposób prowadzenia rejestru zabytków oraz wzory ksiąg rejestru określają przepisy rozporządzenia Ministra Kultury i Dziedzictwa Narodowego z dnia 26 maja 2011 roku w sprawie prowadzenia rejestru zabytków, krajowej, wojewódzkiej i gminnej ewidencji zabytków oraz krajowego wykazu zabytków skradzionych lub wywiezionych za granicę niezgodnie z prawem ${ }^{23}$. Możemy zatem przyjąć, że większość zabytków nieruchomych będzie miała pierwotny wpis oparty na przepisach rozporządzenia z 1963 roku. Pozostanie jeszcze nieliczna grupa obiektów, które zostały wpisane do rejestru na podstawie rozporządzenia prezydenta Rzeczypospolitej z dnia 6 marca 1928 roku o opiece nad zabytkami.

W wyroku NSA z 2013 roku uznano, że decyzja w sprawie wpisania nieruchomości do rejestru zabytków jest zaliczana do decyzji o charakterze rzeczowym, a akty tego rodzaju, w odróżnieniu od aktów o charakterze osobowym i osobowo-rzeczowym, nie dotyczą indywidualnych podmiotów, gdyż mają na celu jedynie uregulowanie statusu prawnego określonej rzeczy. Akty takie są skierowane do rzeczy w oderwaniu od aspektu osobowego, a cecha ta sprawia, że są one w związku z tym nazywane ,aktami administracyjnymi bez adresata" 24 .

W art. 5 ustawy z 2003 roku ustawodawca określił obowiązek sprawowania przez właściciela opieki nad zabytkiem, a wpisanie do rejestru zabytków nakłada na właścicieli obowiązek przestrzegania rygorów ustawy o ochronie zabytków i opiece nad zabytkami. Rola dysponenta zabytku sprowadza się do starannego postępowania w stosunku do zabytku, jak najdłuższego utrzymania zabytku w jak najlepszym stanie oraz jak najlepszego jego wykorzystania dla dobra ogółu ze względu na jego walory historyczne czy naukowe ${ }^{25}$.

Ustalenie kręgu opiekunów prawnych zabytku według tego kryterium może przysparzać jednak wiele trudności. Podstawowym problemem będzie ustalenie podmiotów, które zostały ustawowo zobowiązane do realizacji zadania publicz-

20 Rozporządzenie Ministra Kultury z dnia 14 maja 2004 roku w sprawie prowadzenia rejestru zabytków, krajowej, wojewódzkiej i gminnej ewidencji zabytków oraz krajowego wykazu zabytków skradzionych lub wywiezionych za granicę niezgodnie z prawem, Dz.U. Nr 124, poz. 1305.

${ }^{21}$ Rozporządzenie Ministra Kultury i Dziedzictwa Narodowego z dnia 6 września 2000 roku w sprawie prowadzenia rejestru zabytków i centralnej ewidencji dóbr kultury, Dz.U. Nr 86, poz. 965.

22 Rozporządzenie Rady Ministrów z dnia 23 kwietnia 1963 roku w sprawie prowadzenia rejestru zabytków i centralnej ewidencji zabytków, Dz.U. Nr 19, poz. 101 ze zm.

23 Rozporządzenie Ministra Kultury i Dziedzictwa Narodowego z dnia 26 maja 2011 roku w sprawie prowadzenia rejestru zabytków, krajowej, wojewódzkiej i gminnej ewidencji zabytków oraz krajowego wykazu zabytków skradzionych lub wywiezionych za granicę niezgodnie z prawem, Dz.U. Nr 113, poz. 661.

24 Wyrok NSA z dnia 7 lutego 2013 roku, sygn. II OSK 1841/11, LEX nr 1358415.

25 Wyrok WSA w Warszawie z dnia 24 lutego 2015 roku, sygn. VII SA/Wa 2150/14, CBOSA. 
nego w postaci opieki nad konkretnym zabytkiem. Przykładem takich trudności mogą być „obiekty budowlane wchodzące w skład zabytku ruralistycznego”. WSA uznał również, że ochrona konserwatorska tych obiektów w tym zakresie ogranicza się do „skali, bryły i formy, a także lokalizacji w określonym układzie, natomiast nie dotyczy wystroju wewnętrznego i architektonicznego takiego budynku" ${ }^{26}$. W wyroku z 2010 roku NSA stwierdził, że gdy decyzja o wpisie do rejestru zabytków pochodzi z 1984 roku, to „nie mogą mieć znaczenia dla odczytania zawartych w niej określeń (takich jak obszar czy otoczenie zabytku) przepisy regulacji prawnej z 2003 r." ${ }^{\text {"2 }}$. Z kolei WSA stwierdził, że dane zawarte w rejestrze zabytków, jak i w ewidencji zabytków są danymi publicznymi i podlegają udostępnieniu na podstawie przepisów ustawy o dostępie do informacji publicznej ${ }^{28}$.

W literaturze akcentowane jest przy tym istnienie szeroko rozbudowanej sfery obowiązków opiekuna, co uwypuklają jeszcze liczne sankcje. B. Ruszkiewicz podkreśla, że „wskutek daleko idących sankcji, jakimi jest zagrożona niewłaściwa opieka, można uznać, że na własność zabytków składają się nie tylko uprawnienia, ale przede wszystkim pozytywnie określone obowiązki"29.

Zgodnie z art. 16 ust. 1 ustawy z dnia 15 lutego 1962 roku o ochronie dóbr kultury obiekt mógł zostać skreślony z rejestru zabytków w dwóch przypadkach: gdy uległ całkowitemu zniszczeniu lub gdy jego wartość zabytkowa została zdyskwalifikowana wobec nowych ustaleń naukowych ${ }^{30}$. Na gruncie tej ustawy o wykreśleniu zabytku z rejestru mogła zadecydować również śmierć techniczna budynku, ale nie jedynie zły stan techniczny jego zachowania będący wynikiem wieloletnich zaniedbań, niezabezpieczenia i bieżących prac remontowo-konserwatorskich, do czego zobowiązany był właściciel zabytku

Obecnie, zgodnie z art. 13 ust. 1 ustawy o ochronie zabytków i opiece nad zabytkami z 2003 roku, wpisany do rejestru zabytek, który uległ zniszczeniu w stopniu powodującym utratę jego wartości historycznej, artystycznej lub naukowej albo którego wartość będąca podstawą wydania decyzji o wpisie do rejestru nie została potwierdzona w nowych ustaleniach naukowych, zostaje skreślony z rejestru zabytków. Przepis ten stosuje się odpowiednio do skreślenia z rejestru części zabytku. Dokonując oceny, czy zachodzą wymienione w tym przepisie przesłanki wykreślenia zabytku z rejestru, należy mieć na uwadze, że dobra kultury wpisane do rejestru zabytków podlegają szczególnej ochronie prawnej przewidzianej w ustawie ${ }^{31}$. Skreślenie z rejestru następuje, gdy zabytek wpisany do rejestru uległ

26 Wyrok WSA w Warszawie z dnia 2 czerwca 2015 roku, sygn. VII SA/Wa 1598/14, CBOSA.

27 Wyrok NSA z dnia 18 listopada 2010 roku, sygn. II OSK 1726/09, LEX nr 787125.

28 Wyrok WSA we Wrocławiu z dnia 28 listopada 2012 roku, sygn. IV SAB/Wr 96/12, CBOSA.

29 B. Ruszkiewicz, Wpływ decyzji wojewódzkiego konserwatora zabytków na wykonywanie własności zabytków nieruchomych, [w:] Prawo ochrony zabytków..., s. 327.

30 Wyrok NSA z dnia 16 listopada 2001 roku, sygn. I SA 906/00, CBOSA.

31 Wyrok WSA w Warszawie z dnia 5 października 2006 roku, sygn. I SA/Wa 596/06, LEX nr 295985. 
zniszczeniu w stopniu powodującym utratę jego wartości historycznej, artystycznej lub naukowej albo jego wartość, będąca podstawą wydania decyzji o wpisie do rejestru, nie została potwierdzona w wyniku nowych ustaleń naukowych. Z rejestru skreśla się również zabytek, który został wpisany do inwentarza muzeum, względnie wszedł w skład narodowego zasobu bibliotecznego. Skreślenie z rejestru następuje na podstawie decyzji ministra właściwego do spraw kultury i ochrony dziedzictwa narodowego. Postępowanie w sprawie skreślenia zabytku z rejestru wszczyna się z urzędu bądź na wniosek właściciela zabytku lub użytkownika wieczystego gruntu, na którym znajduje się zabytek nieruchomy.

W tej sytuacji bardzo ważne jest, aby organy „W sposób należyty przeprowadziły postępowanie dowodowe i dokonały prawidłowej oceny zebranego materiału dowodowego, a także w sposób należyty i wyczerpujący uzasadniły rozstrzygnięcie”"32. Jednocześnie WSA uznał, że „konieczność znacznych nakładów na zrekonstruowanie dworu, a tym samym nieopłacalność ekonomiczna takiej inwestycji” nie mogą mieć znaczenia dla rozstrzygnięcia sprawy, gdyż nie stanowią przesłanek z art. 13 ust. 1 ustawy ${ }^{33}$. Podobnie w sprawie skreślenia obiektu z rejestru zabytków nie mogą być brane pod uwagę okoliczności, które spowodowały zniszczenie zabytku, w tym zaniechanie wypełnienia przez niego obowiązków wynikających z art. 5 ustawy $^{34}$. W innym przypadku WSA ocenił, że zły stan techniczny obiektu nie powoduje automatycznie utraty jego wartości zabytkowych ${ }^{35}$.

Współcześnie podstawowym problemem są znaczne rozmiary państwowego rejestru zabytków. Z instytucji podkreślającej wyjątkowy charakter wpisanych do niego zabytków rejestr przekształcił się w zbiór masowy, który w większości obejmuje zabytki o lokalnym lub regionalnym znaczeniu. Utrzymywanie tak rozbudowanego państwowego rejestru zabytków staje się również pretekstem do utrzymywania nadmiernej centralizacji systemu ochrony zabytków.

\section{Ochrona otoczenia zabytku}

Odrębnym problemem jest, przewidywana już w okresie międzywojennym, ochrona otoczenia zabytku. W myśl art. 17 dekretu Rady Regencyjnej rząd miał prawo nie dopuścić do niszczenia, zasłaniania lub szpecenia widoku na zabytki lub z zabytków nieruchomych. W myśl art. 13 tego dekretu zabytki nie mogły być „burzone, niszczone, przerabiane, odnawiane, rekonstruowane, zdobione lub uzupełniane (nawet instalacjami)" bez uprzedniego pozwolenia odpowiedniego organu konserwatorskiego. Takie pozwolenie było wymagane również przy wszelkich

32 Wyrok WSA w Warszawie z dnia 10 maja 2006 roku, sygn. I SA/Wa 1766/05, CBOSA.

33 Wyrok WSA w Warszawie z dnia 15 października 2008 roku, sygn. I SA/Wa 654/08, CBOSA.

34 Wyrok NSA z dnia 14 marca 2008 roku, sygn. II OSK 234/07, CBOSA.

35 Wyrok WSA w Warszawie z dnia 5 października 2006 roku, sygn. I SA/Wa 596/06, CBOSA. 
zmianach zamierzonych w ,najbliższym otoczeniu ważniejszych zabytków nieruchomych". Z kolei w art. 24 rozporządzenia prezydenta z 1928 roku określono, że organy konserwatorskie pierwszej instancji mogły zakazać wszelkich robót, których wykonanie zeszpeciłoby otoczenie zabytku i widok na zabytek lub z zabytku, albo roboty te wstrzymać. W ustawie o ochronie dóbr kultury z 1962 roku w art. 5 pkt 1 przewidywano, że pod względem rzeczowym przedmiotem ochrony mogą być „budowle i ich wnętrza wraz z otoczeniem”. W art. 27 ust. 1 tej ustawy określono, że bez zezwolenia właściwego wojewódzkiego konserwatora zabytków nie wolno zabytków burzyć, niszczyć, przerabiać, odnawiać, rekonstruować, konserwować, zabudowywać, odbudowywać, zdobić, uzupełniać, rozkopywać ani dokonywać żadnych innych zmian, a zgodnie z ust. 3 tego artykułu dotyczyło to również działań mogących przyczynić się do zeszpecenia otoczenia zabytku nieruchomego lub widoku na ten zabytek; chociaż — jak twierdzi J. Pruszyński — nie było stosowane ${ }^{36}$. Należy jednak zauważyć, że oprócz nieprawidłowości działań służb konserwatorskich, na które wskazuje ten autor, na przeszkodzie w egzekwowaniu omawianego przepisu stała również nieprecyzyjność pojęcia widoku na zabytek. W ustawie o ochronie dóbr kultury występowały zatem dwa pojęcia: otoczenia zabytku, które podlegało ochronie prawnej i mogło być wpisane do rejestru (ale nie musiało), oraz widoku na zabytek, którego ochrona była teoretycznie tożsama, ale ponieważ miała charakter ogólny, trudno było ją indywidualnie zakreślić. Jest to więc określony zespół krajobrazowy postrzegany łącznie z zabytkiem. Roztoczenie ochrony wokół obiektu wynika z założenia, że otoczenie jest pewną przestrzenią, która jest z nim fizycznie i funkcjonalnie związana. Ochronie może być poddany nie tylko obszar bezpośrednio przyległy. Zakres ochrony zależy od rozległości kompozycji przestrzennej, a więc obszaru tworzącego z chronionym zabytkiem nieruchomym integralną całość ${ }^{37}$. Warto również zauważyć, że w doktrynie konserwatorskiej zwraca się szczególną uwagę na pojmowanie zabytku jako spójnej całości, na przykład E. Małachowicz na pierwszym miejscu stawia zasadę uwzględnienia integralności obiektu, zespołu i otoczenia ${ }^{38}$. K. Barełkowska zaś stwierdza, że „u podstaw nowoczesnego myślenia o zabytku powinno leżeć jego całościowe postrzeganie jako unikalnego składnika dziedzictwa kultury"39.

W obecnie obowiązującej ustawie o ochronie zabytków i opiece nad zabytkami z 2003 roku zrezygnowano z pojęcia widoku na zabytek, ale pozostawiono termin „otoczenie”. Otoczeniem zabytku, zgodnie z art. 3 pkt 15 tej ustawy, jest

36 J. Pruszyński, op. cit., t. 2, s. 527.

37 K. Zalasińska, Prawna ochrona zabytków nieruchomych w Polsce, Warszawa 2010, s. 221-222.

38 E. Małachowicz, Konserwacja i rewaloryzacja architektury $w$ zespołach i krajobrazie, Wrocław 1994, s. 84.

39 K. Barełkowska, Koegzystencja architektury historycznej i wspótczesnej - bilans wartości dodanej i utraconej w projektach adaptacji funkcjonalno-przestrzennych, [w:] Wartość funkcji w obiektach zabytkowych, red. B. Szmygin, Warszawa 2014, s. 46; zob. B.J. Rouba, Dlaczego adaptacje niszczq zabytki i czy tak być musi?, [w:] Adaptacja obiektów zabytkowych do współczesnych funkcji użytkowych, red. B. Szmygin, Warszawa-Lublin 2009, s. 126. 
„teren wokół lub przy zabytku wyznaczony w decyzji o wpisie tego terenu do rejestru zabytków w celu ochrony wartości widokowych zabytku oraz jego ochrony przed szkodliwym oddziaływaniem czynników zewnętrznych". Istotną nowością tej regulacji jest wprowadzenie formalnego wymogu uzyskania wpisu do rejestru nie tylko samego zabytku, ale i jego otoczenia. W praktyce rozwiązanie to w większości przypadków marginalizuje znaczenie ochrony prawnej otoczenia zabytków, gdyż po prostu nie zostało ono ujęte w rejestrze.

\section{Organy ochrony zabytków i ich kompetencje}

W myśl art. 2 dekretu Rady Regencyjnej opieka nad zabytkami sztuki i kultury należała do Ministerstwa Wyznań Religijnych i Oświecenia Publicznego, ale art. 3 tego dekretu przewidywał, że czynności związane z opieką nad zabytkami sztuki i kultury mieli sprawować konserwatorzy zabytków sztuki i kultury. Podobnie po dziesięciu latach, zgodnie z art. 5 rozporządzenia prezydenta z 1928 roku, opiekę nad zabytkami miały sprawować władze konserwatorskie. Władzami konserwatorskimi były w pierwszej instancji wojewódzkie organy administracji ogólnej, a w drugiej instancji — minister wyznań religijnych i oświecenia publicznego. Zgodnie $\mathrm{z}$ art. 6 rozporządzenia prezydenta z 1928 roku konserwatorzy byli „organami fachowymi” wojewódzkich organów administracji ogólnej, mianowanymi przez ministra wyznań religijnych i oświecenia publicznego. Konserwatorzy należeli do składu personalnego urzędu wojewódzkiego; jeden konserwator mógł pełnić obowiązki w kilku województwach. Do organizacji i funkcjonowania służb konserwatorskich odnosiły się również inne akty prawne, w tym między innymi rozporządzenie prezydenta RP z 1928 roku o postępowaniu administracyjnym ${ }^{40}$, rozporządzenie Rady Ministrów z dnia 23 września 1932 roku o sposobie chronienia przedmiotów zabytkowych, będących własnością Państwa ${ }^{41}$, rozporządzenie prezydenta RP z 1934 roku o unormowaniu właściwości władz i trybu postępowania w niektórych działach administracji państwowej ${ }^{42}$ czy rozporządzenie Ministra Wyznań Religijnych i Oświecenia Publicznego z 1939 roku o podziale obszaru Rzeczypospolitej Polskiej na okręgi konserwatorskie ${ }^{43}$.

40 Rozporządzenie Prezydenta RP z dnia 22 marca 1928 roku o postępowaniu administracyjnym, Dz.U. z 1928 r. Nr 36, poz. 341.

41 Rozporządzenie Rady Ministrów z dnia 23 września 1932 roku o sposobie chronienia przedmiotów zabytkowych, będących własnością państwa, Dz.U. z 1932 r. Nr 89, poz. 750.

42 Rozporządzenie Prezydenta Rzeczypospolitej z dnia 28 grudnia 1934 roku o unormowaniu właściwości władz i trybu postępowania w niektórych działach administracji państwowej, Dz.U. Nr 110, poz. 976 ze zm.

43 Rozporządzenie Ministra Wyznań Religijnych i Oświecenia Publicznego z dnia 24 stycznia 1939 roku o podziale obszaru Rzeczypospolitej Polskiej na okręgi konserwatorskie, Dz.U. z 1939 r. Nr 10, poz. 56. 
Obecnie do organów ochrony zabytków należą, zgodnie z art. 89 ustawy o ochronie zabytków i opiece nad zabytkami z 2003 roku, minister właściwy do spraw kultury i ochrony dziedzictwa narodowego oraz wojewodowie. W imieniu ministra właściwego do spraw kultury i ochrony dziedzictwa narodowego zadania i kompetencje w zakresie ochrony zabytków wykonuje Generalny Konserwator Zabytków (art. 89 pkt 1 ustawy z 2003 roku), który jest sekretarzem lub podsekretarzem stanu w ministerstwie obsługującym ministra właściwego do spraw kultury i ochrony dziedzictwa narodowego (art. 90 ust. 1 ustawy z 2003 roku). Z kolei w imieniu wojewodów zadania i kompetencje w zakresie ochrony zabytków wykonują wojewódzcy konserwatorzy zabytków (art. 89 pkt 2 ustawy z 2003 roku).

Warto również zauważyć, że zaproponowane w okresie międzywojennym usytuowanie terenowych służb konserwatorskich w ramach rządowej administracji zespolonej okazało się rozwiązaniem bardzo trwałym pomimo przejściowego wyodrębnienia jako administracji niezespolonej oraz licznych postulatów rezygnacji $\mathrm{z}$ zespolenia, formułowanych $\mathrm{w}$ ostatnich latach $\mathrm{w}$ środowisku konserwatorskim.

W myśl art. 6 dekretu Rady Regencyjnej właściwe organy rządowe miały prawo badania przedmiotów będących w posiadaniu osób zarówno fizycznych, jak i prawnych w celu ustalenia wartości zabytkowej i zakwalifikowania poszczególnego przedmiotu do inwentarza zabytków sztuki i kultury. Po zakwalifikowaniu właściwy urząd konserwatorski na żądanie właściciela wydawał odpowiednie świadectwo (art. 7 dekretu). Osoba uprawniona do rozporządzania zabytkiem winna zezwolić powołanym do tego organom rządowym na swobodne zbadane zabytku i jego stanu (art. 8 dekretu). Zgodnie $\mathrm{z}$ art. 11 rozporządzenia prezydenta $\mathrm{z} 1928$ roku władze konserwatorskie miały prawo badania wszelkich przedmiotów w celu stwierdzenia ich wartości zabytkowej w miejscach, w których te przedmioty się znajdowały.

W myśl art. 13 dekretu Rady Regencyjnej zabytki nie mogły być „,burzone, niszczone, przerabiane, odnawiane, rekonstruowane, zdobione lub uzupełniane (nawet instalacjami)" bez uprzedniego pozwolenia odpowiedniego organu konserwatorskiego. W myśl art. 14 dekretu Rady Regencyjnej wykonanie — na zasadzie pozwolenia uzyskanego zgodnie z brzmieniem art. 13 - wszelkich robót dotyczących zabytków nieruchomych podlegało kontroli konserwatora, w którym okręgu znajdował się dany zabytek. Konserwator miał prawo wstrzymania robót wykonywanych bez pozwolenia lub niewłaściwie, przy czym mógł korzystać z poparcia miejscowych organów administracyjnych.

W art. 14 rozporządzenia prezydenta z 1928 roku przewidziano, że „zabytków nie wolno burzyć, rozkopywać, niszczyć, przerabiać, odnawiać, rekonstruować, zabudowywać, zdobić, uzupełniać ani przewozić bez uprzedniego zezwolenia władzy konserwatorskiej pierwszej instancji”. Zgodnie z art. 15 tego rozporządzenia wykonywanie wszelkich robót dotyczących zabytku, na zasadzie uzyskanego zezwolenia, podlegało nadzorowi właściwego organu administracji konserwatorskiej pierwszej instancji, która miała prawo wstrzymać roboty wykonywane bez zezwolenia lub 
w sposób niewłaściwy oraz „zmusić właściciela przedmiotu do wykonywania tych robót w sposób właściwy". Ponadto w myśl art. 17 rozporządzenia, jeżeli konkretnym zabytkom groziło niebezpieczeństwo zniszczenia, uszkodzenia lub niedozwolonego wywozu zagranicę, a zwłoka mogłaby spowodować niepowetowaną szkodę, władze konserwatorskie miały prawo, niezależnie od zarządzeń wydawanych na zasadzie art. 16, wydawać zarządzenia zmierzające do zapobieżenia wywozowi zabytku za granicę, a nawet przekazać takie zabytki na określony czas w zarząd państwowy, w szczególności przenieść je do muzeów, archiwów lub bibliotek państwowych bądź publicznych aż do usunięcia występującego niebezpieczeństwa. $\mathrm{Z}$ kolei w art. 20 rozporządzenia przyznano Skarbowi Państwa prawo pierwokupu sprzedawanego przez właściciela zabytku ruchomego bądź nieruchomego.

Przywołane regulacje z okresu międzywojennego zostały znacznie wzbogacone i rozszerzone w kolejnych ustawach, zwłaszcza w ustawie o ochronie zabytków i opiece nad zabytkami z 2003 roku, w której przyznano wojewódzkiemu konserwatorowi zabytków kompetencje do wydania decyzji administracyjnej w przedmiocie wstrzymania prac, badań lub robót wykonywanych bez pozwolenia konserwatorskiego lub w sposób odbiegający od zakresu i warunków określonych w tym pozwoleniu. Wojewódzki konserwator zabytków może też wydać decyzję nakazującą osobie fizycznej lub jednostce organizacyjnej mającej tytuł prawny do korzystania z zabytku wynikający z tytułu własności, użytkowania wieczystego, trwałego zarządu albo ograniczonego prawa rzeczowego lub stosunku zobowiązaniowego przeprowadzenie $\mathrm{w}$ terminie określonym $\mathrm{w}$ tej decyzji prac konserwatorskich lub robót budowlanych przy tym zabytku, jeżeli ich wykonanie jest niezbędne ze względu na zagrożenie zniszczeniem lub istotnym uszkodzeniem zabytku.

We współczesnych ustawodawstwie (zwłaszcza w ustawie z 2003 roku) dostrzec można zjawisko narastającej i nieczytelnej ingerencji w prawa właścicieli zabytków. Pogłębia je charakter decyzji administracyjnej wojewódzkiego konserwatora zabytków. NSA podkreślił, że decyzja administracyjna podejmowana w tym przedmiocie ma charakter uznaniowy, co w praktyce oznacza, że sądowa kontrola takiej decyzji jest ograniczona do zbadania, czy nie nosi ona cech dowolności, a nie zajmuje się celowością bądź słusznością takiego rozstrzygnięcia ${ }^{44}$.

Liczne ograniczenia prawa własności oraz restrykcyjny charakter wielu regulacji dotyczących zabytków są — według J. Pruszyńskiego — uzasadnione tym, że ochronę zabytków i opiekę nad zabytkami zaliczamy do zadań publicznych, czyli takich, których wypełnianie jest uzasadniane interesem publicznym zachowania konkretnych przedmiotów i utrzymania ich w stanie uznanym za właściwy środkami prawnymi i organizacyjnymi państwa ${ }^{45}$. Pogląd ten uzyskał akceptację i rozwinięcie w wyroku Trybunału Konstytucyjnego z dnia 8 października 2007 roku. Podstawowy problem podniesiony przez TK dotyczy kwestii, „w jakiej mierze

44 Wyrok NSA z dnia 23 września 2016 roku, sygn. II OSK 156/15, CBOSA.

45 J. Pruszyński, op. cit., t. 1, s. 157. 
państwo może zobowiązać właściciela (inwestora) do ponoszenia ciężarów związanych z realizacją obowiązku państwa - »strzeżenia dziedzictwa narodowego《

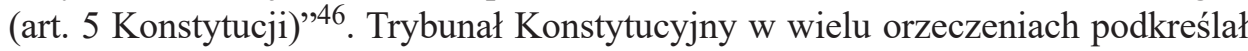
znaczenie zasady proporcjonalności, wywodząc, że ograniczenia praw i wolności mogą być wprowadzane jedynie w sytuacji, gdy okaże się to „konieczne w demokratycznym państwie", co nakazuje za każdym razem badać, czy za pomocą danego ograniczenia uda się osiągnąć zamierzone skutki, czy unormowanie to jest niezbędne do ochrony interesu publicznego, któremu ma służyć, oraz czy efekty owego ograniczenia pozostają w proporcji do ciężaru nałożonego na obywatela ${ }^{47}$. Ponadto Trybunał Konstytucyjny wielokrotnie podkreślał, że prawo do równego traktowania winno być ujmowane w związku z konkretnymi normami prawnymi lub działaniami organów władzy publicznej, a nie w oderwaniu od nich ${ }^{48}$.

\section{Podsumowanie}

Podsumowując przywołane w tekście uwagi, z konieczności skoncentrowane jedynie na wybranych zagadnieniach, i dokonując oceny międzywojennych rozwiązań prawnych dotyczących zabytków, należy podkreślić, że wprawdzie regulacje te wywodziły się z różnych koncepcji XIX wieku, lecz charakteryzowały się nowoczesnym (w tamtym czasie) spojrzeniem na problematykę ochrony zabytków. W szczególności należy w pełni potwierdzić przywołany na początku pogląd o szczególnej, fundamentalnej, roli regulacji prawnych z okresu międzywojennego względem budowy systemu prawa opieki nad zabytkami (ochrony zabytków) w Polsce.

Dokonując z kolei z tej perspektywy skróconej oceny obecnych regulacji, należy zauważyć, że niewielki wpływ prawa europejskiego w tej dziedzinie przyniósł w rezultacie nie tylko ustabilizowanie, ale i stagnację modelu pochodzącego sprzed stu laty. Ponadto trzeba dostrzec znaczną żywotność podstawowych problemów, z którymi próbowano się uporać na początku ubiegłego stulecia, co znajduje odzwierciedlenie zarówno w literaturze przedmiotu, jak i w orzecznictwie. Wynika to w dużym stopniu z archaiczności wielu współczesnych regulacji, które bywają nawet regresem w stosunku do swoich pierwowzorów (wadliwa regulacja prawna otoczenia zabytku, znaczne rozmiary rejestru zabytków, narastająca i nieczytelna ingerencja w prawa właścicieli zabytków itp.). Najważniejsze jest jednak to, że współcześnie regulacje prawne dotyczące zabytków obejmują znacznie mniejszy fragment rozrastającej się sfery ochrony prawnej dziedzictwa. W literaturze trafnie podkreśla się, że system ochrony zabytków jest jedynie czę-

46 Wyrok TK z dnia 8 października 2007 roku, sygn. K 20/07, OTK-A 2007, nr 9, poz. 102.

47 Wyrok TK z dnia 29 czerwca 2001 roku, sygn. K 23/00, OTK 2001, nr 5, poz. 124.

48 Wyrok TK z dnia 19 lipca 2005 roku, sygn. SK 20/03, OTK-A 2005, nr 7, poz. 82; oraz wyrok TK z dnia 6 października 2004 roku, sygn. SK 23/02, OTK-A 2004, nr 9, poz. 89. 
ścią — podsystemem - szeroko rozumianego systemu społeczno-gospodarczego w danym kraju, a więc wpływa na niego wiele znajdujących się poza jego kontrolą czynników politycznych, społecznych i ekonomicznych ${ }^{49}$. Odnosi się to również do oceny funkcjonowania współczesnego systemu ochrony zabytków w Polsce. W pełni podzielam pogląd J. Purchli, którego zdaniem

dotychczasowy system ochrony zabytków to typowy przykład administracji reglamentacyjnej, posługującej się przede wszystkim nakazami i zakazami. [...] Tymczasem tylko umiejętne i harmonijne włączenie dziedzictwa do wielkiej zmiany cywilizacyjnej, której jesteśmy świadkami, daje gwarancję jego skutecznej ochrony ${ }^{50}$.

Niestety, współczesny ustawodawca nie dostrzega tych uwarunkowań i podtrzymuje archaiczne rozwiązania, co w dużym stopniu wpływa na ograniczenie możliwości podejmowania działań na rzecz istotnej poprawy, jak dotąd wciąż złego, stanu zabytków w Polsce.

\section{Bibliografia}

Barełkowska K., Koegzystencja architektury historycznej i wspótczesnej-bilans wartości dodanej i utraconej w projektach adaptacji funkcjonalno-przestrzennych, [w:] Wartość funkcji w obiektach zabytkowych, red. B. Szmygin, Warszawa 2014.

Bukal G., Produkcja zabytków jako problem konserwatorski (przykład Gdańska), [w:] Wspótczesne problemy teorii konserwatorskiej w Polsce, red. B. Szmygin, Warszawa-Lublin 2008.

Drela M., Definicja zabytku nieruchomego w prawie polskim i francuskim, „Ochrona Zabytków” $2008, \mathrm{nr} 1$.

Małachowicz E., Konserwacja i rewaloryzacja architektury w zespołach i krajobrazie, Wrocław 1994.

Murzyn-Kupisz M., Fiskalno-prawne uwarunkowania systemu ochrony zabytków w Polsce. Wybrane problemy, [w:] System ochrony zabytków w Polsce — analiza, diagnoza, propozycje, red. B. Szmygin, Lublin-Warszawa 2011.

Płażyńska K., Świadectwo minionej epoki czy dobro kultury wspótczesnej? Problemy ochrony prawnej architektury nowoczesnej, [w:] Prawo ochrony zabytków, red. K. Zeidler, Gdańsk 2014.

Pruszyński J., Dziedzictwo kultury Polski. Jego straty i ochrona prawna, t. 1-2, Kraków 2001.

Purchla J., Dziedzictwo kulturowe w Polsce: system prawny, finansowanie i zarzadzanie, [w:] Kultura a rozwój, red. J. Hausner, A. Karwińska, J. Purchla, Warszawa 2013.

Rouba B.J., Dlaczego adaptacje niszczq zabytki i czy tak być musi?, [w:] Adaptacja obiektów zabytkowych do wspótczesnych funkcji użytkowych, red. B. Szmygin, Warszawa-Lublin 2009.

Rouba B.J., Teoria w praktyce polskiej ochrony, konserwacji i restauracji dziedzictwa kultury, [w:] Wspótczesne problemy teorii konserwatorskiej w Polsce, red. B. Szmygin, Warszawa-Lublin 2008.

49 M. Murzyn-Kupisz, Fiskalno-prawne uwarunkowania systemu ochrony zabytków w Polsce. Wybrane problemy, [w:] System ochrony zabytków w Polsce - analiza, diagnoza, propozycje, red. B. Szmygin, Lublin-Warszawa 2011, s. 119.

50 J. Purchla, Dziedzictwo kulturowe w Polsce: system prawny, finansowanie i zarzadzanie, [w:] Kultura a rozwój, red. J. Hausner, A. Karwińska, J. Purchla, Warszawa 2013, s. 203-204. 
Ruszkiewicz B., Wpływ decyzji wojewódzkiego konserwatora zabytków na wykonywanie własności zabytków nieruchomych, [w:] Prawo ochrony zabytków, red. K. Zeidler, Gdańsk 2014.

Szmelter I., Paradygmat teorii i praktyki konserwatorskiej w odniesieniu do sztuki nowoczesnej, [w:] Wspótczesne problemy teorii konserwatorskiej w Polsce, red. B. Szmygin, Warszawa-Lublin 2008.

Szmygin B., Teksty doktrynalne w ochronie dziedzictwa - analiza formalna i propozycje, [w:] Wspótczesne problemy teorii konserwatorskiej w Polsce, red. B. Szmygin, Warszawa-Lublin 2008 .

Tomaszewski A., Ekumenizm kulturowy w jednoczacej się Europie, [w:] O zabytkach. Opieka, ochrona, konserwacja, red. T. Rudkowski, Warszawa 2005.

Zalasińska K., Prawna ochrona zabytków nieruchomych w Polsce, Warszawa 2010.

Zimna-Kawecka K., Ochrona zabytków i organizacja urzędów konserwatorskich w Polsce okresu międzywojennego (na przykladzie woj. pomorskiego) a unormowania Ustawy z dn. 23 VII 2003 r. o ochronie zabytków i opiece nad zabytkami, „Wiadomości Konserwatorskie” 2010, nr 27.

\title{
Remarks on interwar legislation on the care of monuments, and contemporary model
}

\begin{abstract}
Summary
The modern system of monument protection in Poland is derived from solutions adopted in the interwar period. Particular importance is attributed to the decree on the care of monuments of art and culture passed by the Regency Council in 1918. The decree was the first legal act regarding the care and protection of monuments. The legal system of monument protection in the interwar period was finally shaped by the provisions of the Regulation of the President of the Republic of Poland issued on March 6, 1928 regarding the care of monuments. At present, the view about the special and fundamental role of legal regulations from the interwar period for the construction of the system of the care and protection of monuments should be fully confirmed. In particular, terminology problems are still relevant today. In the Polish legal system, regarding the role of the state in relation to cultural heritage, three terms with a similar meaning have been adopted: "guarding", "protection" and "care". It should be noted that the latest law (Act of 23 July 2003) gave the concept of "care of monuments" a different meaning than that adopted in the interwar period. Today, in the 21 st century, care over a monument is exercised by its owner or holder and consists in particular in ensuring appropriate conditions for preserving such a monument. In addition, it should be noted that the fundamental problems that existed and attempts made to solve them at the beginning of the last century, have still not been solved, which is reflected in both the literature and case law.
\end{abstract}

Keywords: monument protection, care of monuments, interwar period.

Prawo 331, 2020

(C) for this edition by CNS 